九州大学学術情報リポジトリ

Kyushu University Institutional Repository

\title{
アトピー性皮膚炎発症におけるIL-13/ペリオスチ ン/IL-24経路を介した表皮バリア破壊機構の解析
}

\section{三田村，康貴}

http://hdl. hand le. net/2324/1959088

出版情報：Kyushu University，2018，博士（医学），課程博士 バージョン：

権利関係: Public access to the fulltext file is restricted for unavoidable reason (2) 
論 文 名：The IL-13/periostin/IL-24 pathway causes epidermal barrier dysfunction in allergic skin inflammation

(アトピー性皮膚炎発症における IL-13/ペリオスチン/IL-24 経路を介した 表皮バリア破壊機構の解析)

区 分：甲

\section{論 文内容の要旨}

表皮バリア破壊は代表的な 2 型サイトカインである IL-4 や IL-13 により起 こり、アトピー性皮膚炎 (AD) の発症に重要である。また、IL-4 や IL-13によ り誘導される細胞外マトリックスタンパク質のペリオスチンがバリア破壊 を含めたアレルギー性皮膚炎発症に重要である。しかし、ペリオスチンがど のように IL-13 刺激の下流で皮膚バリア破壊を引き起こすのかは不明であっ た。本研究で、我々はペリオスチン依存的にIL-13により誘導されるIL-24 を同定した。ケラチノサイトは、ペリオスチン依存的に IL-13により STAT6 を介して IL-24を誘導する主な組織構成細胞であった。IL-24 は IL-13/ペリ オスチン経路の下流でSTAT3を介してフィラグリンの発現を低下させ、バリ ア破壊に関与した。野生型ダ二処置皮膚炎モデルマウスにおいて見られた IL-24 産生克進、STAT3 のリン酸化、フィラグリン低下が、STAT 6 およびペリ オスチン欠損マウスで消失したため、これらはSTAT6とペリオスチンの下流 で生じている事を示唆した。更に、アトピー性皮膚炎患者の表皮で IL-24の 産生が増加していた。IL-24はIL-13/ペリオスチン経路の下流でケラチノサ イトにより誘導され、アトピー性皮膚炎患者の表皮バリア破壊に重要である ことを明らかにした。 